\title{
Temperature Effects on the Corrosion Inhibition of Mild Steel in Sulfuric Acid Solution by Acacia senegal Gum with Halide Ions
}

\author{
Jovine Emmanuel $^{1 *}$ and Joseph Buchweishaija ${ }^{2}$ \\ ${ }^{*}$ Chemistry Department, Mkwawa University College of Education, P.O. Box 2513 Iringa, \\ Tanzania.E-mail: jovineemma2007@yahoo.co.uk \\ ${ }^{2}$ Chemistry Department, University of Dar es Salaam, P. O. Box 35061, Dar es Salaam \\ Tanzania.E-mail: jbuchwa@yahoo.com \\ *Corresponding author
}

Received 11 Jun 2021, Revised 14 Oct 2021, Accepted 23 Oct 2021, Published Dec 2021

DOI: https://dx.doi.org/10.4314/tjs.v47i5.9

\begin{abstract}
The effects of temperature on the inhibitive effect of naturally occurring Acacia senegal gum exudate on the corrosion of mild steel in sulfuric acid was studied between 35 and $70{ }^{\circ} \mathrm{C}$ using electrochemical impedance spectroscopy and potentiodynamic polarization methods. Findings showed that Acacia senegal gum exudate decreases the corrosion rate of mild steel. The inhibition efficiency declined with raising temperature above $35{ }^{\circ} \mathrm{C}$. The increase in the corrosion rate with increasing temperature was observed for both uninhibited and inhibited systems. Addition of halide ions to the Acacia senegal gum exudate solution enhanced the corrosion inhibition efficiency because of synergistic effects, achieving higher performance with iodide ions as compared to bromide ions. However, the synergistic effects declined above $35{ }^{\circ} \mathrm{C}$ up to $70{ }^{\circ} \mathrm{C}$ due to temperature effects. It has been observed that increasing temperature adversely affected inhibition efficiencies of both Acacia senegal gum exudate and the synergy between Acacia senegal gum exudate and halide ions. Corrosion rates of mild steel, inhibition efficiencies of Acacia senegal gum exudate and the synergistic effects of halide ions from polarization and impedance measurements were consistent.
\end{abstract}

Keywords: temperature, corrosion, mild steel, synergistic effects, Acacia senegal, gum exudate.

\section{Introduction}

The effect of temperature on a chemical reaction is of practical importance. As in most chemical reactions, the rate of corrosion of iron and steel increases with increasing temperature especially corrosion of steel in acidic media (Umoren et al. 2008a, 2008b, Eddy 2009a, Eddy 2009b, Umoren et al. 2010, Kairi and Kassim 2013). In such environment where steel is in contact with acidic media, corrosion inhibitors are always used to protect steel from corrosion (Saratha and Vasudha 2009, Shaju et al. 2012). However, it is common for chemical inhibitors to lose their chemical integrity when applied at higher temperatures which can lead to poor performance (Khaleel et al. 2018). Generally, acid pickling of steel is usually carried out at elevated temperatures of up to $70{ }^{\circ} \mathrm{C}$ in sulfuric acid solutions (Abd ElMaksoud 2008, Mobin et al. 2011, Kairi and Kassim 2013, Khan et al. 2015). Accordingly, inhibitors that are used are expected to be chemically stable and provide high performance of protection under operating conditions of such temperature. We reported in the recent publication on the synergistic effects of halide ions and Acacia senegal gum exudate inhibitors for mild steel corrosion in acidic media at $35{ }^{\circ} \mathrm{C}$ (Emmanuel and Buchweishaija 2021). The objective of the present work was to study the effects of 
temperature on mild steel corrosion in $0.5 \mathrm{M}$ $\mathrm{H}_{2} \mathrm{SO}_{4}$ solution in the absence and presence of $300 \mathrm{ppm}$ Acacia senegal gum exudate and $0.08 \mathrm{M}$ halide ions.

\section{Materials and methods}

The investigation was carried out in a conventional three electrode system $(50 \mathrm{~mL})$ Pyrex glass cell in the Chemistry Department, University of Dar es Salaam. Mild steel electrode was used as a working electrode, a saturated calomel electrode (SCE) and platinum electrode as a reference and counter electrode, respectively. The specimen composition and electrodes preparation procedures are similar to that reported elsewhere (Emmanuel and Buchweishaija 2021) where all working electrodes were wet abraded with 320 to 800 grit silicon carbide papers then polished with diamond paste in order to achieve mirror finishing surfaces. All chemicals used were of analytical grade and were used without further purification and solutions were prepared using distilled water. The corrosive medium was prepared by diluting concentrated sulfuric acid $(96 \%)$ by Panreal Quimica SA with distilled water to $0.5 \mathrm{M} \mathrm{H}_{2} \mathrm{SO}_{4}$. The halides used were $99.5 \%$ $\mathrm{KBr}$ by $\mathrm{MB}$ England and $99.8 \% \mathrm{KI}$ by Techno Pharmchem, Bahadurgarh, India at a concentration of $0.08 \mathrm{M}$. The corrosion inhibitor tested in this study was a commercial Acacia senegal gum supplied by $\mathrm{BDH}$ Laboratory Chemicals Division, Poole, England. The finely ground Acacia senegal gum exudate powder was dissolved in distilled water to form solutions based on ppm (parts per million) units. The concentrations of the Acacia senegal gum exudate used in this study was $300 \mathrm{ppm}$.

The prepared electrodes were mounted on the rotating disc electrode system and introduced in the glass cell containing the test solution ready for electrochemical measurements. The same procedures were followed for each experiment. Experiments were performed at solution temperature of 35 ${ }^{\circ} \mathrm{C}, 50{ }^{\circ} \mathrm{C}, 60{ }^{\circ} \mathrm{C}$ and $70{ }^{\circ} \mathrm{C}$ and the $\mathrm{pH}$ of the test solutions was $0.7 \pm 0.2$. The $\mathrm{pH}$ used resembles the practical environment where sulfuric acid is widely used to remove deposits and in acid pickling operations for scale elimination. The solution temperature was controlled by passing thermostated water through the jacketed cell throughout the experiment.

Electrochemical experiments were performed by using the Voltlab 80 PGZ402 potensiostat. The working electrode was left immersed in the test solution under Open Circuit Potential (OCP) for 30 minutes to attain a steady state OCP value before the measurements were taken. Both cathodic and anodic potentiodynamic polarization curves were registered over the potential range from 600 to $-400 \mathrm{mV}$ vs SCE at a scan rate of 1.0 $\mathrm{mV} / \mathrm{s}$. The linear Tafel segments of anodic and cathodic curves were extrapolated to corrosion potential, $E_{\text {corr, }}$ to acquire the corrosion current density $\left(i_{\text {corr }}\right)$. Electrochemical impedance spectroscopy (EIS) measurements were conducted at OPC over the frequency range $100 \mathrm{kHz}$ down to 0.1 $\mathrm{Hz}$ at an amplitude of $10 \mathrm{mV}$ and scan rate of 10 points per decade (Martinez and Stern 2002, Khan et al. 2015, Kulandai and Vasudha 2015). The Nyquist curves of the impedance data were analyzed using the Microsoft Office Excel. The charge transfer resistance was obtained from the diameter of the semicircle of the Nyquist plots.

\section{Results and Discussion}

Typical polarization curves and impedance plots in Nyquist format at different system conditions are presented in Figures 1 and 2, respectively. 


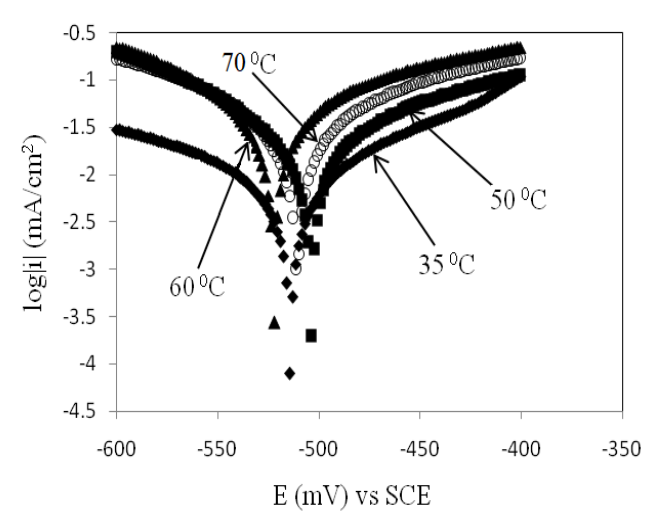

(a)

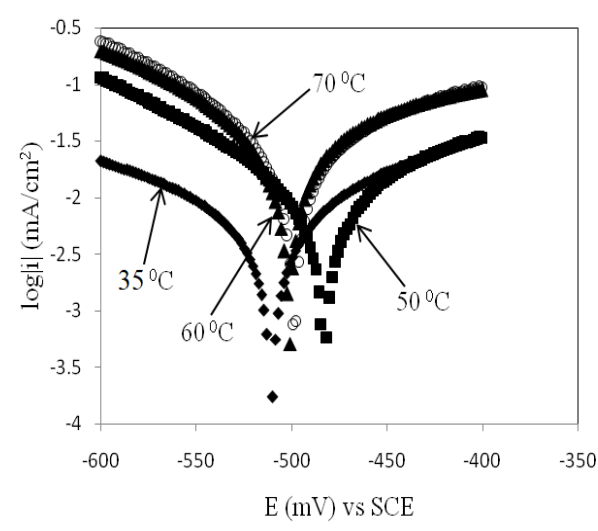

(b)

Figure 1: Potentiodynamic polarization curves for mild steel electrodes in $0.5 \mathrm{M} \mathrm{H}_{2} \mathrm{SO}_{4}$ at different solutions temperature with (a) mixture of $300 \mathrm{ppm}$ Acacia senegal gum exudate and $0.08 \mathrm{M} \mathrm{KBr}$, (b) mixture of $300 \mathrm{ppm}$ Acacia senegal gum exudate and $0.08 \mathrm{M} \mathrm{KI}$.

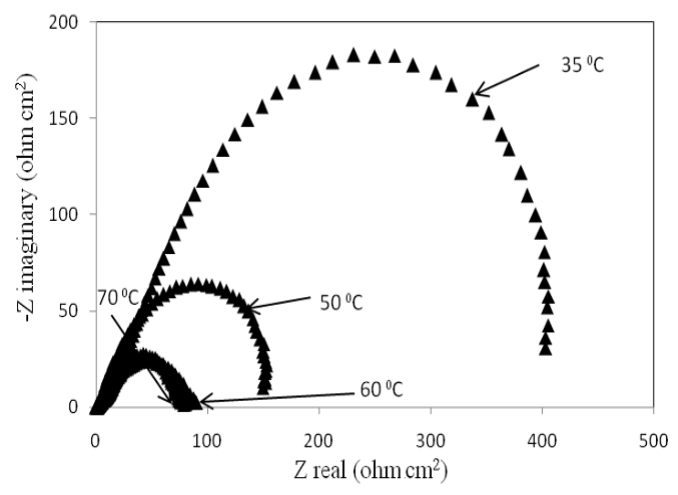

(a)

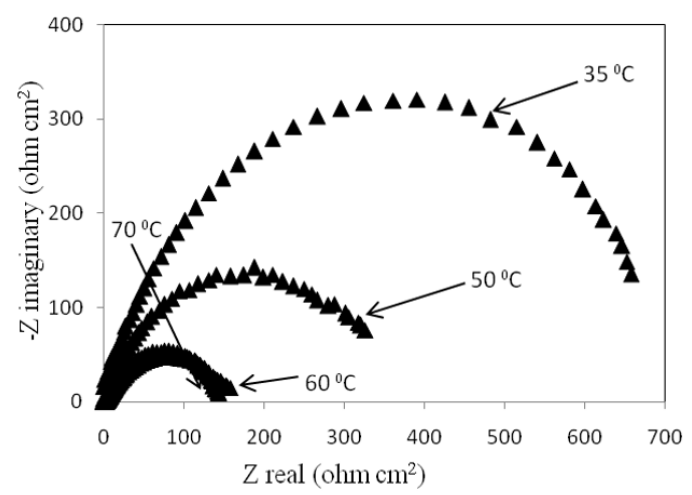

(b)

Figure 2: Impedance plot in Nyquist format for mild steel electrodes in $0.5 \mathrm{M} \mathrm{H}_{2} \mathrm{SO}_{4}$ at different solutions temperature with (a) mixture of $300 \mathrm{ppm}$ Acacia senegal gum and $0.08 \mathrm{M} \mathrm{KBr}$ and (b) mixture of $300 \mathrm{ppm}$ Acacia senegal gum and $0.08 \mathrm{M} \mathrm{KI}$.

Tables 1 and 2 show the calculated values of corrosion rates and inhibition efficiencies for mild steel in $0.5 \mathrm{M} \mathrm{H}_{2} \mathrm{SO}_{4}$ for different systems at different temperatures that were generated from potentiodynamic polarization and electrochemical impedance results, respectively. 
Table 1: The calculated values from potentiodynamic polarization curves for corrosion rates (mmpy) and corrosion inhibition effeciency $\left(\mathrm{I}_{\text {eff }}\right)$ for mild steel in $0.5 \mathrm{M} \mathrm{H}_{2} \mathrm{SO}_{4}$ in different systems at different temperatures

\begin{tabular}{lcccccccc}
\hline \multirow{2}{*}{ System } & \multicolumn{3}{c}{ Corrosion rate (mmpy) } & \multicolumn{3}{c}{ Inhibition Efficiency $(\%)$} \\
\cline { 2 - 8 } & $35{ }^{\circ} \mathrm{C}$ & $50{ }^{\circ} \mathrm{C}$ & $60{ }^{\circ} \mathrm{C}$ & $70{ }^{\circ} \mathrm{C}$ & $35^{\circ} \mathrm{C}$ & $50{ }^{\circ} \mathrm{C}$ & $60{ }^{\circ} \mathrm{C}$ & $70{ }^{\circ} \mathrm{C}$ \\
\hline Blank & $3.5 \times 10^{-8}$ & $4.6 \times 10^{-8}$ & $1.2 \times 10^{-7}$ & $1.9 \times 10^{-7}$ & - & - & - & - \\
$300 \mathrm{ppm}$ & $1.9 \times 10^{-8}$ & $3.5 \times 10^{-8}$ & $9.2 \times 10^{-8}$ & $1.2 \times 10^{-7}$ & 43.3 & 25.0 & 21.0 & 20.6 \\
$300 \mathrm{ppm}+$ & $1.8 \times 10^{-8}$ & $3.0 \times 10^{-8}$ & $7.7 \times 10^{-8}$ & $1.0 \times 10^{-8}$ & 46.7 & 35.0 & 34.0 & 45.3 \\
$0.08 \mathrm{M} \mathrm{KBr}$ & & & & & & & & \\
$300 \mathrm{ppm}+$ & $8.1 \times 10^{-9}$ & $1.6 \times 10^{-8}$ & $4.9 \times 10^{-8}$ & $7.0 \times 10^{-8}$ & 76.7 & 66.0 & 58.0 & 64.7 \\
$0.08 \mathrm{M} \mathrm{KI}$ & & & & & & & & \\
\hline
\end{tabular}

Table 2: The calculated values of corrosion rates from electrochemical impedance curves in terms of reciprocal of charge transfer resistance $\left(\Omega^{-1} \mathrm{~cm}^{-2}\right)$ and corrosion inhibition effeciency $\left(\mathrm{I}_{\text {eff }}\right)$ for mild steel in $0.5 \mathrm{M} \mathrm{H}_{2} \mathrm{SO}_{4}$ in different systems at different temperatures

\begin{tabular}{lcccccccc}
\hline System & \multicolumn{3}{c}{$\left(\mathrm{R}_{\mathrm{ct}}\right)^{-1} /\left(\Omega^{-1} \mathrm{~cm}^{-2}\right) \times 10^{-3}$} & \multicolumn{4}{c}{ Inhibition Efficiency $(\%)$} \\
\cline { 2 - 9 } & $35^{\circ} \mathrm{C}$ & $50{ }^{\circ} \mathrm{C}$ & $60{ }^{\circ} \mathrm{C}$ & $70{ }^{\circ} \mathrm{C}$ & $35^{\circ} \mathrm{C}$ & $50{ }^{\circ} \mathrm{C}$ & $60{ }^{\circ} \mathrm{C}$ & $70{ }^{\circ} \mathrm{C}$ \\
\hline Blank & 12.5 & 13.0 & 19.0 & 32.0 & - & - & - & - \\
$300 \mathrm{ppm}$ & 7.6 & 8.3 & 13.0 & 22.0 & 39.2 & 36.2 & 31.6 & 31.3 \\
$300 \mathrm{ppm}+0.08 \mathrm{M} \mathrm{KBr}$ & 2.4 & 7.0 & 12.0 & 20.0 & 68.4 & 46.2 & 36.8 & 37.5 \\
$300 \mathrm{ppm}+0.08 \mathrm{M} \mathrm{KI}$ & 1.4 & 3.1 & 6.4 & 10.0 & 81.6 & 76.2 & 66.3 & 68.8 \\
\hline
\end{tabular}

Results show that corrosion rates for the blank systems increased as the system temperature was raised from $35{ }^{\circ} \mathrm{C}$ to $70{ }^{\circ} \mathrm{C}$ as shown in Table 1. For the inhibited systems, corrosion rates were also observed to increase as the temperature was elevated. A significant drop in the corrosion rates has been observed by the addition of halide ions, Figure 1. The effect of temperture on the synergistic effect of halide ions on corrosion inhibition of mild steel by Acacia senegal gum exudate is also evidenced by the decreased size of the semicircles with progresive increase of temperature as shown in Figure 2. Findings have shown that when temperature was raised, the inhibition efficiency of Acacia senegal gum exudate and the synergystic effect of halide ions subsequently declined. Thus, temperature has an adverse effect on the performance of Acacia senegal gum exudate corrosion inhibitor. A decline in the inhibition efficiency with increasing temperature has been attributed to desorption of some of the adsorbed inhibitor molecules from the metal surface at higher temperatures (Mobin et al.
2011). The inhibition efficiency of Acacia senegal gum exudate was increased by the addition of halide ions (i.e. $\mathrm{Br}^{-}$and $\mathrm{I}^{-}$) even at $70{ }^{\circ} \mathrm{C}$ due to synergistic effects, Figure 1 and 2. These observations are consistent with previous studies reported elsewhere (Olusegun et al. 2004, Noor 2007, Umoren et al. 2008a, Umoren et al. 2008b, Oguzie 2008, Obot 2009, Obot et al. 2012, Kairi and Kassim 2013, Kulandai and Vasudha 2015). Synergistic effects of halide ions increased in the order $\mathrm{Br}^{-}<\mathrm{I}^{-}$. As the temperature was raised to $50{ }^{\circ} \mathrm{C}, 60^{\circ} \mathrm{C}$ and $70{ }^{\circ} \mathrm{C}$, respectively, the size of the semicircles decreased significantly as shown in Figures 3 a-d. The size of the semicircles for the blank systems at the studied temperatures was also observed to diminish with increasing temperature implying the increase in the corrosion rates of mild steel in acidic solutions with increasing temperature. A substantial increase in the size of the semicircles was observed when halide ions were added. Thus, halide ions enhanced the inhibition efficiency of Acacia senegal gum exudate in acidic media even at high temperature although a slight decline was 
observed. For instance, the enhancement effects declined from $81.6 \%$ at $35^{\circ} \mathrm{C}$ to $68.8 \%$ at $70{ }^{\circ} \mathrm{C}$ for Acacia senegal gum exudate with iodide ions. On the other hand, the enhancement effects declined from $68.4 \%$ at $35^{\circ} \mathrm{C}$ to $37.5 \%$ at $70{ }^{\circ} \mathrm{C}$ for Acacia senegal gum exudate with bromide ions. A summary of the calculated values from impendance measurements for Acacia senegal gum exudate is shown in Table 2. The charge transfer resistance increased systematically from blank to inhibited systems and from inhibited to inhibited-halide ions mixtures systems for each particular temperature studied. The inhibition efficiency of Acacia senegal gum exudate followed a similar trend. However, iodide ions revealed greater corrosion inhibition enhancement effects compared to bromide ions. Findings showed that corrosion inhibition enhencement effects depend on the ionic size and charge, electrostatic field set up by the negative charge of the anion on adsorption sites and the nature and concentrations of the halide ions (Abd El-Maksoud 2008, Emmanuel and Buchweishaija 2021). The order was $81.6 \%$, $76.2 \%, 66.3 \%$ and $68.8 \%$ at $35^{\circ} \mathrm{C}, 50{ }^{\circ} \mathrm{C}, 60$
${ }^{\circ} \mathrm{C}$ and $70{ }^{\circ} \mathrm{C}$, respectively, while that of bromide ions was $68.4 \%, 46.2 \%, 36.8 \%$ and $37.5 \%$ at $35{ }^{\circ} \mathrm{C}, 50{ }^{\circ} \mathrm{C}, 60{ }^{\circ} \mathrm{C}$ and $70{ }^{\circ} \mathrm{C}$, respectively.

Synergistic effects of halide ions on the corrosion inhibition of mild steel by Acacia senegal gum exudate in acidic media is also affected by the raise in temperature, Figure 3. This is evidenced by the decrease in the size of the semicircles with progresive increase in temperature. Consequently, the corrosion inhibition enhancement by halide ions declined slightly as the temperature was raised. Thus, greater corrosion inhibition enhancement was achieved at low temperature, about $35^{\circ} \mathrm{C}$. Similar observation on the decline of corrosion inhibition efficiency of mild steel by Nypa fruticans's wurmb extract and iodide ions mixture with increasing temperature was reported elsewhere (Orubite-Okorosaye et al. 2007). A summary of electrochemical parameters from polarization measurements showing the important trends in the corrosion current densities and corrosion inhibition efficiencies at different temperatures in this study is presented in Table 3. 


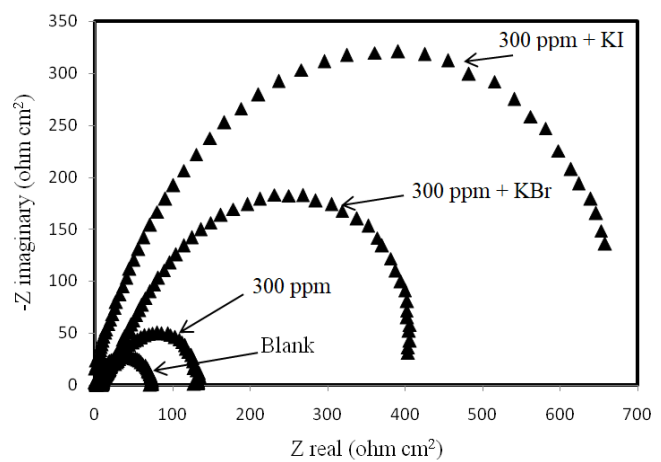

(a)

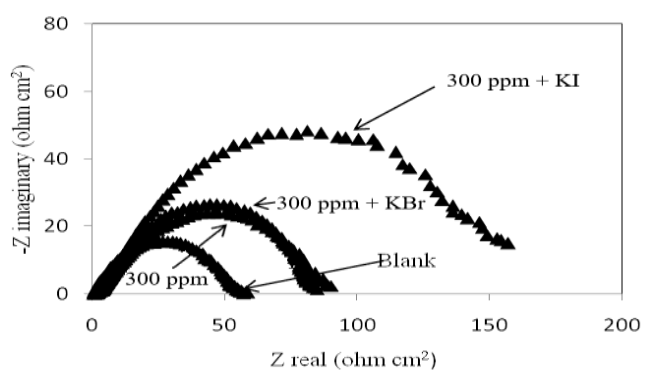

(c)

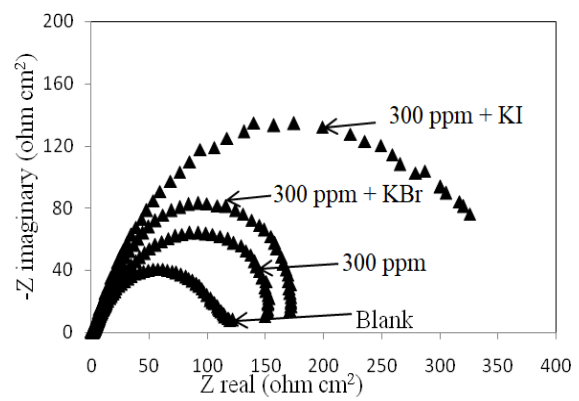

(b)

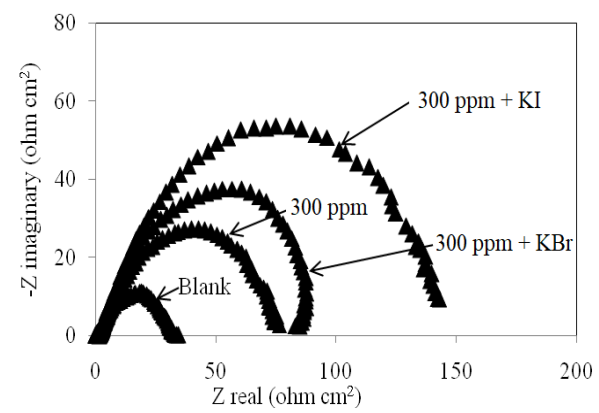

(d)

Figure 3: Impedance plot in Nyquist format for mild steel in $0.5 \mathrm{M} \mathrm{H}_{2} \mathrm{SO}_{4}$ in the absence and presence of $300 \mathrm{ppm}$ Acacia senegal gum exudate, mixture of $300 \mathrm{ppm}$ Acacia senegal gum exudate and $0.08 \mathrm{M} \mathrm{KBr}$ and mixture of $300 \mathrm{ppm}$ Acacia senegal gum exudate and $0.08 \mathrm{M} \mathrm{KI}$ solutions at (a) $35^{\circ} \mathrm{C}$, (b) $50{ }^{\circ} \mathrm{C}$, (c) $60{ }^{\circ} \mathrm{C}$ and (d) $70{ }^{\circ} \mathrm{C}$.

As it can be seen in Table 3, the corrosion inhibition efficiency of Acacia senegal gum exudate inhibitor declined at higher temperature. Notwithstanding, a slight decline in the corrosion inhibition enhancement by halide ions was observed at $50{ }^{\circ} \mathrm{C}, 60{ }^{\circ} \mathrm{C}$ and $70{ }^{\circ} \mathrm{C}$, respectively. Generally, halide ions retained their enhancement effects even at higher temperature, with iodide ions achieving higher enhancement effects as comapred to bromide ions, consistent with previous synergistic findings reported elsewhere (Umoren et al. 2008b, Obot 2009). These findings indicate that higher temperatures have adverse effects on the mild steel corrosion inhibition efficiency of various green inhibitors. 
Table 3: The corrosion current densities and corrosion inhibition efficiencies from polarization measurements of various systems of Acacia senegal gum exudate (300 ppm) at $35^{\circ} \mathrm{C}, 50{ }^{\circ} \mathrm{C}, 60{ }^{\circ} \mathrm{C}$ and $70{ }^{\circ} \mathrm{C}$

\begin{tabular}{llll}
\hline $\begin{array}{l}\text { Temperature } \\
\left({ }^{\circ} \mathrm{C}\right)\end{array}$ & Experimental Condition & $\mathrm{i}_{\text {corr }}\left(\mathrm{mA} / \mathrm{cm}^{2}\right)$ & $\mathrm{I}_{\text {eff }}(\%)$ \\
\hline \multirow{3}{*}{35} & Blank & 0.0030 & - \\
& Inhibited & 0.0017 & 43.3 \\
50 & Inhibited $+\mathrm{KBr}$ & 0.0016 & 46.7 \\
& Inhibited $+\mathrm{KI}$ & 0.0007 & 76.7 \\
& Blank & 0.0040 & - \\
& Inhibited & 0.0030 & 25 \\
60 & Inhibited $+\mathrm{KBr}$ & 0.0026 & 35 \\
& Inhibited $+\mathrm{KI}$ & 0.0014 & 66 \\
& Blank & 0.0100 & - \\
& Inhibited & 0.0079 & 21 \\
70 & Inhibited $+\mathrm{KBr}$ & 0.0066 & 34 \\
& Inhibited $+\mathrm{KI}$ & 0.0042 & 58 \\
& Blank & 0.017 & - \\
& Inhibited & 0.0135 & 20.6 \\
& Inhibited $+\mathrm{KBr}$ & 0.0089 & 45.3 \\
& Inhibited $+\mathrm{KI}$ & 0.0060 & 64.7 \\
\hline
\end{tabular}

\section{Conclusion}

The effects of temperature on the corrosion inhibition efficiency of mild steel by naturally occurring Acacia senegal gum exudate in sulfuric acid media was studied at $35-70{ }^{\circ} \mathrm{C}$ by using electrochemical impedance spectroscopy and potentiodynamic polarization techniques. The corrosion inhibition efficiency declined with raising temperature up to $70{ }^{\circ} \mathrm{C}$. The increase in the corrosion rates with increasing temperature was observed for both uninhibited and inhibited systems. The addition of halide ions to the Acacia senegal gum exudate solutions enhanced the corrosion inhibition efficiency because of synergistic effects and the enhancement effects declined slightly with increasing temperature due to temperature effects. An increase of temperature increased the corrosion rates of mild steel as temperature adversely affected the inhibition efficiencies of Acacia senegal gum exudate and the synergistic effects of halides ions.

\section{Acknowledgement}

The authors acknowledge Mkwawa University College of Education for financial support for this study.

\section{References}

Abd El-Maksoud SA 2008 The effect of organic compounds on the electrochemical behaviour of steel in acidic media. A review. Int. J. Electrochem. Sci. 3: 528-555.

Eddy NO 2009a Ethanol extract of Phyllanthus amarus as a green inhibitor for the corrosion of mild steel in $\mathrm{H}_{2} \mathrm{SO}_{4}$. Port. Electrochim. Acta 27(5): 579-589.

Eddy NO 2009b Inhibitive and adsorption properties of ethanol extract of Colocasia esculenta leaves for the corrosion of mild steel in $\mathrm{H}_{2} \mathrm{SO}_{4}$. Int. J. Phys. Sci. 4(4): 165171.

Emmanuel J and Buchweishaija J 2021 Synergistic effects of halide ions and Acacia senegal gum on the corrosion inhibition of mild steel in sulfuric acid solution. Tanz. $J$. Sci. 47(2): 686-697.

Kairi NI and Kassim J 2013 The effect of temperature on the corrosion inhibition of mild steel in $1 \mathrm{M} \mathrm{HCl}$ solution by Curcuma longa extract. Int. J. Electrochem. Sci. 8: 7138-7155.

Khaleel H, Ateeq AA and Ali AA 2018 The effect of temperature and inhibitor on corrosion of carbon steel in acid solution under static study. Int. J. Appl. Eng. Res. 13(6): 3638-3647. 
Khan G, Newaz KMS, Basirun WJ, Ali HBM, Faraj FL and Khan GM 2015 Application of natural product extracts as green corrosion inhibitors for metals and alloys in acid pickling processes: A review. Int. J. Electrochem. Sci. 10: 6120-6134.

Kulandai TS and Vasudha VG 2015 Thermodynamic and adsorption studies for corrosion inhibition of mild steel using Millingtonia hortensis. Int. J. Inf. Res. Rev. 2: 261-266.

Martinez S and Stern I 2002 Thermodynamic characterization of metal dissolution and inhibitors adsorption processes in the low carbon steel/sulfuric acid system. Appl. Surf. Sci. 199: 83-89.

Mobin M, Khan MA and Parveen M 2011 Inhibition of mild steel corrosion in acidic medium using starch and surfactants additives. J. Appl. Polym. Sci. 121: 15581565.

Noor EA 2007 Temperature effects on the corrosion inhibition of mild steel in acidic solutions by aqueous extract of Fenugreek leaves. Int. J. Electrochem. Sci.2(12): 9961017.

Obot IB, Ebenso EE and Gasem ZM 2012 Ecofriendly corrosion inhibitors: adsorption and inhibitive action of ethanol extracts of Chlomolaena odorata $L$. for the corrosion of mild steel in $\mathrm{H}_{2} \mathrm{SO}_{4}$ solutions. Int. J. Electrochem. Sci. 7: 1997-2008.

Obot IB 2009 Synergistic effect of nizoral and iodide ions on the corrosion iof mild steel in sulphuric acid solution. Port. Electrochim. Acta 27(5): 539-553.

Oguzie EE 2008 Corrosion inhibitive effect and adsorption behaviour of Hibiscus sabdariffa extract on mild steel in acidic media. Port. Electrochim. Acta 26: 303-314.
Olusegun AK, Oforka NC and Ebenso EE 2004 The inhibition of mild ateel corrosion in an acidic medium by the juice of Citrus paradisi (grapefruit). J. Corros. Sci. Eng. 8: $1-5$.

Orubite-Okorosaye K, Jack IR, Ochei M and Akaranta O 2007 Synergistic effect of potassium iodide on corrosion inhibition of mild steel in $\mathrm{HCl}$ medium by extracts of Nypa fruticans' wurmb. J. Appl. Sci. Environ. Manag. 11(2): 27-31.

Saratha R and Vasudha VG 2009 Inhibition of mild steel corrosion in $1 \mathrm{~N} \mathrm{H}_{2} \mathrm{SO}_{4}$ medium by acid extract of Nyctanthes arbotristis leaves. E-J. Chem. 6(4): 1003-1008.

Shaju KS, Thomas KJ, Raphael VP and Paul A 2012 Synergistic effect of KI on corrosion inhibition of mild steel by polynuclear schiff base in sulphuric acid. Int. Schol. Res. Netw. 2012.

Umoren SA, Solomon MM, Udosoro II and Udoh AP 2010 Synergistic and antagonistic effects between halide ions and carboxymethyl cellulose for the corrosion inhibition of mild steel in sulphuric acid solution. Cellulose 17: 635-648.

Umoren SA, Obot IB, Ebenso EE and ObiEgbedi N 2008a Studies on the inhibitive effect of exudate gum from Dacroydes edulis on the acid corrosion of aluminium. Port. Electrochim. Acta 26: 199-209.

Umoren SA, Obot IB, Ebenso EE and ObiEgbedi NO 2008b Synergistic inhibition between naturally occurring exudate gum and halide ions on the corrosion of mild steel in acidic medium. Int. J. Electrochem. Sci. 3: 1029-1043. 